\title{
Akad Musyarakah Dalam Pembiayaan Perdagangan Dan Pertanian Di Lembaga Keuangan Mikro Agribisnis (LKMA) Syariah Barokah
}

\author{
Mas'ut, Soim \\ IAI Pangeran Diponegoro Nganjuk \\ masud.iaipadienganjuk@gmil.com
}

\begin{abstract}
:
Partnership-based products with profit sharing such as Musharaka as the competitive superior product of Islamic banking have not experienced growth like other products. The lack of development of partnership-based products in Islamic banking that is more flexible in terms of term, especially long-term financing, causes Islamic banking to have more of its products based on fixed income financing which is similar to the conventional pattern which uses a fixed income structure and tends to be short term. and medium. At LKMA Syariah Barokah, it has a superior product, namely musyarakah. Musyarakah is a profit sharing contract when two or more entrepreneurs holding funds / capital work together as business partners, financing new or existing business investments. Business partners who own capital are entitled to participate in company management, but it is not mandatory. The parties can divide the work of managing the business according to their agreement and can also ask for salaries / wages for the labor and expertise they devote to the business
\end{abstract}

Keywords: Musyarakah Financing, Trade Financing, Agricultural Financing

\section{PENDAHULUAN}

Ekonomi dalam Islam merupakan suatu konsep yang utuh sebagai sistem, yang jika diterapkan secara kaffah akan mampu mengatasi persoalan-persoalan ekonomi yang mungkin muncul. Hanya saja sayangnya, belum banyak orang yang menyadari, termasuk juga sebagian orang islam sendiri, tentang betapa pentingnya penataan ekonomi berdasarkan sistem atau prinsip - prinsip ber-Muamalah khususnya bidang ekonomi yang Islami.

Prinsip-prinsip ber-Muamalah dalam ekonomi Islam jelas akan bermanfaat untuk meningkatkan pemahaman dan kesadaran pentingnya sistem ekonomi ini dalam penataan kehidupan sehari-hari. Dengan kesadaran tersebut, muncul harapan terhadap perilaku ekonomi, baik pada tingkat individu ataupun masyarakat, yang akan cenderung pada bentuk yang diwarnai oleh Islam. Artinya, rujukan utama dalam penataan ekonomi akan bertumpu pada hukum-hukum ekonomi yang Islami sifatnya ${ }^{1}$

Permodalan masih menjadi salah satu permasalahan utama yang dihadapi pelaku usaha masyarakat, khususnya petani. Untuk mengatasi permasalahan tersebut, pemerintah memberikan solusi dengan meluncurkan suatu program yang dinamakan Program Pengembangan Usaha Agribisnis Perdesaan (PUAP) melalui pemberian dana Bantuan

${ }^{1}$ Masyhuri, Teori Ekonomi dalam Islam, Yogyakarta, Kreasi Wacana, 2015. 
Langsung Masyarakat sebagai modal usaha tani bagi petani, sekaligus untuk memperbaiki dan memperkuat kelembagaan ekonomi di perdesaan yang akhirnya bermuara pada berkembangnya Lembaga Keuangan Mikro Agribisnis (LKM-A) di perdesaan. LKM-A yang berbasis syariah pun juga ada. Mereka mempunyai produk-produk diantaranya Musyarakah, mudhorabah, murabahah, Rohn, dan lain-lain. Lembaga keuangan syariah yang kiranya cukup berkembang dan salah satu lembaga keuangan yang ada dalam gabungan kelompok tani (GAPOKTAN) di Kab Nganjuk adalah Lembaga Keuangan Mikro Agribisnis (LKMA) Syariah Barokah, yang berada di Ds. Ngepeh Kecamatan Loceret

Di LKMA Syariah Barokah ini mempunyai produk unggulan yaitu musyarakah. Musyarakah merupakan akad bagi hasil ketika dua atau lebih pengusaha pemilik dana/modal bekerja sama sebagai mitra usaha, membiayai investasi usaha baru atau yang sudah berjalan. Mitra usaha pemilik modal berhak ikut serta dalam manajemen perusahaan, tetapi itu tidak merupakan keharusan. Para pihak dapat membagi pekerjaan mengelola usaha sesuai kesepakatan dari mereka juga dapat meminta gaji/upah untuk tenaga dan keahlian yang mereka curahkan untuk usaha tersebut. ${ }^{2}$

Dalam rangka merespon dinamika sosial terkait kesadaran bertransaksi secara syariah, para ahli ekonomi Syariah mencoba mengkonstruksi model lembaga keuangan yang bisa melayani transaksi keuangan bebas riba. Oleh karena itu, penyelarasan produk dan jasa perbankan syariah dengan norma dan prinsip syariah bersifat mutlak dalam operasional perbankan syariah. Terkait dengan norma dan nilai syariah dalam transaksi ekonomi, banyak ulama yang mengemukakan kaidah fiqih muamalah yang menegaskan bahwa segala sesuatu dalam muamalah bersifat boleh, kecuali yang dilarang dalam hukum syariah.

Harapan masyarakat terhadap layanan perbankan syariah di Indonesia terus menunjukkan peningkatan, yang ditandai dengan semakin bertambahnya segmen maupun jumlah nasabah. Hal tersebut secara esensial didasari oleh keinginan masyarakat pelaku ekonomi dan perbankan untuk menyelaraskan seluruh aktivitas keuangannya dengan ajaran syariah yang diyakini.

Produk berbasis kemitraan dengan bagi hasil seperti Musyarakah sebagai produk unggulan kompetitif perbankan syariah belum mengalami pertumbuhan sebagaimana produk lainnya. Kurangnya pengembangan produk berbasis kemitraan di perbankan syariah yang lebih fleksibel jangka waktunya, terutama pembiayaan jangka panjang menyebabkan perbankan syariah lebih banyak produknya didasari oleh pembiayaan dengan pendapatan tetap yang memiliki kemiripan dengan pola konvensional yang menggunakan struktur pendapatan yang tetap (fixed income) dan cenderung berjangka waktu pendek dan menengah.

\section{METODE PENELITIAN}

\section{a. Pendekatan dan Jenis Penelitian}

Ditinjau dari jenis datanya, yang digunakan dalam penelitian ini adalah pendekatan kualitatif. Penelitian kualitatif bertujuan mengembangkan konsep sensitivitas pada masalah yang dihadapi, menerangkan realitas yang berkaitan dengan penelusuran teori

\footnotetext{
${ }^{2}$ Ascarya, Akad \& Produk Bank Syariah. Jakarta: PT. Raja Grafindo Persada, 2015, 51.
} 
dari bawah (grounded theory) dan mengembangkan pemahaman akan satu atau lebih dari fenomena yang dihadapi. Penelitian merupakan sebuah metode penelitian yang digunakan dalam mengungkapkan permasalahan dalam kehidupan kerja organisasi pemerintah swasta, kemasyarakatan, kepemudaan perempuan olahraga, seni dan budaya, sehingga dapat dijadikan suatu kebijakan untuk dilaksanakan demi kesejahteraan bersama.

Adapun jenis pendekatan penelitian ini adalah deskriptif. Penelitian deskriptif yaitu penelitian yang berusaha untuk menuturkan pemecahan masalah yang ada sekarang berdasarkan data-data. Jenis penelitian deskriptif kualitatif yang digunakan pada penelitian ini dimaksudkan untuk memperoleh informasi mengenai Akad Musyarakah dalam Pembiayaan Perdagangan dan Pertanian. Selain itu, dengan pendekatan kualitatif diharapkan dapat diungkapkan beberapa dampak yang terjadi dalam masyarakat.

\section{b. Kehadiran Peneliti}

Dalam penelitian ini, peneliti bertindak sebagai pengumpul data dan sebagai instrument aktif dalam upaya mengumpulkan data-data di lapangan. sedangkan instrument pengumpulan data yang lain selain manusia adalah berbagai bentuk alat-alat Bantu dan berupa dokumen-dokumen lainnya yang dapat digunakan untuk menunjang keabsahan hasil penelitian, namun berfungsi sebagai instrument pendukung.

\section{c. Lokasi Penelitian}

Obyek dari penelitian ini adalah mengenai Akad Musyarakah yang ada di LKMA Syariah Barokah, Ds. Ngepeh Kec Loceret, Kab. Nganjuk, Jawa Timur. Karena lembaga ini merupakan satu-satunya lembaga keuangan mikro agribisnis yang menggunakan akad syaria'ah yang ada di kabupaten Nganjuk.

\section{d. Data dan Sumber Data}

Menurut ahli bahasa sumber ialah asal, sedangkan data adalah keterangan yang benar dan nyata. Dengan demikian sumber data, berarti asal keterangan yang didapat, hal ini senada dengan pendapat yang dikemukakan oleh Muchtar bahwa sumber dalam penelitian adalah sumber-sumber yang dimungkinkan seorang peneliti mendapatkan sejumlah informasi.

Senada dengan keterangan diatas, data adalah suatu fakta yang dapat digambarkan dengan angka, simbol, kode dan lain-lain.

\section{1) Sumber Data Utama (Primer)}

Sumber data utama yang dimaksudkan adalah sumber utama yang dapat memberikan informasi, fakta dan gambaran peristiwa yang di inginkan dalam penelitian. Atau sumber pertama dimana sebuah data dihasilkan. ${ }^{3}$ Dalam penelitian kualitatif, sumber data utama itu adalah kata-kata dan tindakan orang-orang yang diamati atau wawancara terhadap informasi atau pihak-pihak yang bersangkutan senantiasa bertujuan memperoleh informasi yang diperlukan di LKMA Syariah Barokah Desa Ngepeh, Kecamatan Loceret,

\footnotetext{
${ }^{3}$ Ibrahim, Metode Penelitian Kualitatif, Alfa Beta, Bandung, Mei 2015:69
} 
Kabupaten Nganjuk. Adapun yang menjadi kunci informasi dengan rincian sebagai berikut:

a) Manajer atau Kepala LKMA Syariah Barokah Desa Ngepeh, Kecamatan Loceret, Kabupaten Nganjuk.

b) Staf Adminitrasi LKMA Syariah Barokah desa Ngepeh, Kecamatan Loceret, Kabupaten Nganjuk.

2) Sumber Data Tambahan (Sekunder)

Sementara sumber data tambahan adalah segala bentuk dokumen, baik dalam bentuk tertulis maupun foto. Atau sumber data kedua sesudah sumber data primer. Meskipun disebut sebagai sumber kedua, dokumen tidak bisa diabaikan dalam suatu penelitian, terutama dokumen tertulis seperti buku, majalah ilmiah, arsip, dokumen pribadi dan dokumen resmi, sebagaimana dikutip oleh Ibrahim dalam Moleong. ${ }^{4}$

\section{e. Prosedur Pengumpulan Data}

Sebuah penelitian dapat dikatakan berhasil apabila data dapat dikumpulkan. Sebaliknya, jika data tidak bisa didapatkan atau tidak dapat dikumpulkan, masa sebuah penelitian dipandang tidak berhasil alias gagal. Di antara teknik pengumpulan data yang lazim digunakan dalam penelitian kualitatif menurut penulis adalah, observasi, wawancara, dokumentasi berikut penjelasannya masing-masing.

\section{1) Wawancara}

Wawancara adalah salah satu perangkat metodologi favorit bagi peneliti kualitatif. Wawancara menurutnya adalah bentuk perbincangan, seni bertanya dan mendengar. Wawancara bukanlah perangkat netral dalam memproduksi realitas. Jadi wawancara merupakan perangkat untuk memproduksi pemahaman situasional yang bersumber dari episode-episode intraksional khusus.

\section{2) Pengamatan}

Secara terminologi, observasi berasal dari istilah inggris observation yang bermakna pengamatan, pandangan, pengawasan. Atau dalam kata keterangan sebagai observe yang berarti mengamati, melihat, meninjau, menjalankan, mematuhi, memperhatikan, menghormati. Karena itu, observasi menurut Kaelan adalah pengamatan atau peninjauan secara cermat. Menurutnya observasi atau pengamatan merupakan teknik pengumpulan data yang paling utama dalam penelitian. Karena itu banyak teori dan ilmu pengetahuan dalam sejarah ditemukan melalui observasi.

3) Dokumentasi

Dokumen atau dokumentasi dalam penelitian mempunyai dua makna yang sering dipahami secara keliru oleh penelitian pemula. Pertama, dokumen yang dimaksudkan

\footnotetext{
${ }^{4}$ Ibrahim, Metodologi Penelitian Kualitatif, Bandung: Alfabeta, 2015: 69
} 
sebagai alat bukti tentang sesuatu, termasuk catatan-catatan, foto, rekaman video atau apapun yang dihasilkan oleh seorang peneliti. Dokumen bentuk ini lebih cocok disebut sebagai dokumentasi kegiatan/kenang-kenangan. Kedua, dokumen yang berkenaan dengan peristiwa atau momen atau kegiatan yang telah lalu, yang padanya mungkin dihasilkan sebuah informasi, fakta dan data yang diinginkan dalam penelitian.

\section{f. Analisis Data}

Analisa data adalah proses mencari dan menyusun secara sistematis data yang diperoleh dari hasil wawancara, catatan lapangan dan dokumentasi dengan cara mengorganisasikan data ke dalam kategori, menjabarkan ke dalam unit-unit, melakukan sintesa, menyusun ke dalam pola, memilih mana yang penting dan yang akan dipelajari dan membual kesimpulan sehingga mudah dipahami oleh diri sendiri maupun orang lain. Dengan kata lain menganalisis data maksudnya adalah menetapkan tahap-tahap, langkahlangkah kegiatan terhadap data yang sedang dan sudah dikumpulkan dengan tujuan menarik kesimpulan. ${ }^{5}$

Setiap penelitian pasti memerlukan adanya analisis data. Analisis data merupakan kegiatan yang sangat penting dalam penelitian. Bahkan penelitian ini sendiri adalah bagian dari kerja analisis yang dilakukan oleh seorang ilmuwan. Apalagi dalam penelitian kualitatif, pekerjaan analisis tidak dapat dipisahkan dengan penelitian itu sendiri. Artinya bahwa, kegiatan penelitian dimulai, pada saat itu juga pekerjaan analisis juga sudah berjalan dalam pendekatan kualitatif. ${ }^{6}$

\section{HASIL DAN PEMBAHASAN}

\subsection{Hasil Penelitian}

\section{Bentuk Akad Musyarakah}

Dari paparan data dan penemuan data pada bab sebelumnya, LKMA Syariah Barokah mempunyai usaha ekonomi produktif, dalam rangka mewujudkan visi dan misi lembaga. Usaha tersebut untuk menggalang dan menghimpun dana yang dipergunakan untuk pembiayaan usaha-usaha anggota. Usaha tersebut adalah usaha simpanan dan pembiayaan.

Dari temuan yang di ungkap oleh karyawan LKMA, yakni Syafi'i, bahwa tidak semua produk bisa berjalan semua. Seperti halnya produk pembiayaan, ada mudharabah, musyarakah, murabahah, Qordul Hasan, Ar Rahn, dan ijrah. Sekian banyak itu yang berjalan kini adalah hanya akad musyarakah, mudaharabah dan Ijarah.

Dari wawancara yang dilakukan kepada Puspito, selaku manager LKMA, penulis menggaris bawahi bahwa musyarakah merupakan kerjasama antara pemilik modal dengan seseorang atau lebih untuk suatu usaha tertentu dimana masing-masing pihak memberikan kontribusi dana dengan kesepakatan bahwa keuntungan dan resiko akan

\footnotetext{
${ }^{5}$ Samiudin, Problematika Penulisan Spenelitian, Panca Wahana, Vol. 10, No. 1, 2015.94

${ }^{6}$ Ibrahim, Metodologi Penelitian Kualitatif, Bandung: Alfabeta, 2015, 103.
} 
ditanggung bersama sesuai dengan kesepakatan, yakni membagi keuntungan, menikmati hak-hak dan tanggung jawab yang sama.

Temuan-temuan ini ternyata sama dengan yang di ungkapkan oleh Acaranya yang intinya bahwa musyarakah merupakan akad bagi hasil ketika dua atau lebih pengusaha pemilik dana/modal bekerja sama sebagai mitra usaha, membiayai investasi usaha baru atau yang sudah berjalan. Mitra usaha pemilik modal berhak ikut serta dalam manajemen perusahaan, tetapi itu tidak merupakan keharusan. Para pihak dapat membagi pekerjaan mengelola usaha sesuai kesepakatan dari mereka juga dapat meminta gaji/upah untuk tenaga dan keahlian yang mereka curahkan untuk usaha tersebut.

Yang pada umumnya musyarakah merupakan perjanjian yang berjalan terus sepanjang usaha yang dibiayai bersama terus beroperasi. Meskipun demikian, perjanjian musyarakah dapat diakhiri dengan atau tanpa menutup usaha. Apabila usaha ditutup dan dilikuidasi asset sesuai nisbah penyertaanya. Apabila usaha terus berjalan, maka mitra usaha yang ingin mengakhiri perjanjian dapat menjual sahamnya ke mitra usaha yang lain dengan harga yang disepakati bersama. ${ }^{7}$

Di LKMA sendiri mempunyai prinsip yang syariah, seperti yang paparkan oleh manager LKMA, bahwa LKMA Syariah Barokah berprinsip bahwa kerjalah yang menghasilkan uang, bukan uang menghasilkan uang. Ketika mengajukan pembiayaan tentu akadnya adalah membagi hasil dari yang dikerjakan (pertanian maupun perdagangan). Jika yang kerjakan itu tidak berhasil atau gagal panen, maka tentunya tidak ada hasilnya. Kalau tidak ada hasilnya, apa yang dibagi? Jadi tidak ada yang dibagi, karena akad di awal adalah bagi hasil.

Hal ini dilakukan tentunya dalam rangka menegakkan kemaslahatan dan sebagai wujud seorang muslim harus bekerja sama dalam hal kebaikan, serta memberikan kemudahan bagi masing-masing pihak untuk melaksanakan akad musyarakah. Namun, para pihak yang melaksanakan akad harus menyadari bahwa keduanya memiliki kedudukan yang setara, yakni memiliki hak dan kewajiban yang seimbang, yang mana keduanya harus sportif untuk mencapai kemaslahatan.

Wujud LKMA Syariah Barokah dalam saling membantu antara sesama ini dalam hal kebaikan ini, serupa dengan firman Allah dalam Al-Qur'an surat Al Maidah ayat 2 yang tercamtum dalam SOP dan SOM LKMA Syariah Barokah, yaitu:

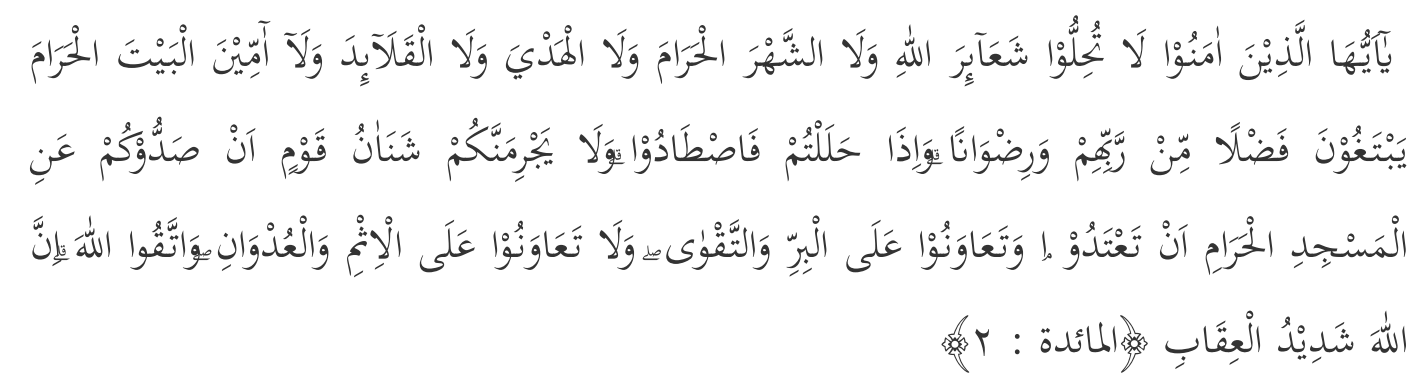

${ }^{7}$ Ascarya, Akad \& Produk Bank Syariah. Jakarta: PT. RajaGrafindo Persada, 2015, 51-52 
Artinya: "Wahai orang-orang yang beriman! janganlah kamu melanggar syi'ar-syi'ar kesucian Allah, dan jangan (melanggar kehormatan) bulan-bulan haram, jangan (mengganggu) hadyu (hewan-hewan kurban), dan qalaid (hewan-hewan kurban yang diberi tanda), dan jangan (pula) mengganggu orang-orang yang mengunjungi mereka mencari kurnia dan keredhaan Tuhannya, tetapi apabila kamu telah menyelesaikan ihram maka bolehl kamu berburu. Janganlah sampai kebencian(mu) kepada sesuatu kaum karena mereka menghalang-halangi kamu dari Masjidilharam, mendorongmu berbuat melampaui bata (kepada mereka). Dan tolong-menolong lah kamu dalam (mengerjakan) kebajikan dan takwa, dan jangan tolong-menolong dalam berbuat dosa dan permusuhan. Bertakwalah kamu kepada Allah, Sungguh, Allah sangat berat siksaNya" (QS Al Maa-idah 5:2 $)^{8}$

\section{Bentuk Pembiayaan Perdagangan dan Pertanian}

Menurut penulis, bentuk pembiayaan yang ada pada LKMA Syariah Barokah ini yang paling banyak digunakan adalah menggunakan akad musyarakah. Pembiayaan di LKMA ini berpedoman bahwa bagi hasil yang diberikan kepada lembaga merupakan hasil dari usaha anggota. Karena dalam pembiayaan, LKMA memberikan kontribusi dana kepada anggota untuk modal usaha, atau memperbesar usaha yang ada. Seperti yang diungkapkan oleh mas Syafi' $i$, saat ditemui penulis di kantor LKMA, bahwa pembiayaan yang diberikan kepada anggota ini untuk pengembangan usaha yang sudah ada, yang semula usahanya satu item barang, ditambah beberapa jenis barang yang lain. Tentunya semuanya itu akan dibiayai oleh pihak lembaga setelah anggota mengajukan pembiayaan.

Dilihat dari pengertian tentang pembiayaan yang ada di LKMA diatas, hal ini seirama dengan apa yang ada dalam Undang-Undang nomor 10 tahun 1998 diungkapkan oleh Anik Rahayu, bahwa Pembiayaan adalah Suatu penyediaan uang atau tagihan yang dipersamakan dengan itu berdasarkan persetujuan atau kesepakatan antara bank dengan pihak lain yang mewajibkan pihak yang dibiayai untuk mengembalikan uang atau tagihan tersebut setelah jangka waktu tertentu dengan imbalan atau bagi hasil. ${ }^{9}$

Sedangkan akad musyarakah yang diterapkan dalam pembiayaan ini, di LKMA Syariah Barokah mayoritas lebih cenderung dalam membiayai usaha-usaha modal kerja. Seperti dalam pertanian dan juga perdagangan. Yang dikarenakan masyarakat setempat mayoritas pekerjaannya dalah seorang petani, dan usahanya adalah pedagang sebagai penjual bakso, industri rumah tangga, pracangan dan lain-lain. Yang keseluruhannya menggunakan akad musyarakah.

Hal ini pernah diungkapkan Syafi'i, selaku karyawan LKMA, bahwa pihak lembaga sendiri juga tidak mau dirugikan, maka pengajuan-pengajuan pembiayaan yang di setujui oleh pihak lembaga adalah usaha yang nyata-nyata sudah ada dan berjalan, walaupun usaha tersebut tidak besar. Dan bapak Puspito selaku Manager LKMA juga

${ }^{8}$ Usman el-Qurthuby, Multazam Al-Qur'an Tafsir Bil Hadis, Bandung, Cordoba, 2016,106.

9 Anik Rahayu, Akuntansi Akad Musyarakah Mutanaqisah dalam Pembiayaan Kredit Pemilikan Rumah pada PT.Bank Muamalat, Jurnal Ilmu \& Riset Akuntansi Vol. 2 No. 11 2013,2. 
menambahkan, bahwa akad musyarakah disini mengaplikasikannya cenderung bidang pertanian. Tapi hingga saat ini dalam musyarakah membiayai usaha dalam bidang pertanian dan perdagangan.

Sama halnya yang dipaparkan oleh Ascarya tentang produk pembiayaan, Dari sekian banyak produk pembiayaan bank syariah, tiga produk pembiayaan utama yang mendominasi portofolio pembiayaan bank syariah adalah pembiayaan modal kerja, pembiayaan investasi, dan pembiayaan aneka barang dan property.

Kebutuhan pembiayaan modal kerja dapat dipenuhi dengan berbagai cara, antara lain:
a. Bagi hasil: mudharabah, musyarakah; dan
b. Jual beli: murabahah, salam. ${ }^{10}$

Sedangkan proses pengajuan pembiayaan musyarakah ini pihak LKMA ini sangatlah mudah dan praktis, sesuai dengan prinsip kerja sama ini, Hal ini terbukti dari SOP dan MOP yang ada di LKMA Syariah Barokah ini dalam prosedur pengajuan pembiayaan. Prosedur pengajuan pembiayaan di LKMA antara lain adalah: ${ }^{11}$

a. Mendaftar jadi anggota yang telah ditetapkan di ART LKMA Syariah Barokah

b. Mengisi formulir pengajuan pembiayaan

c. Memiliki usaha atau pekerjaan tetap

d. Jujur, amanah, dan bertanggung jawab

e. Bersedia disurvey dirumah atau ditempat usaha

f. Mempunyai agunan/ jaminan atau penjamin dari anggota untuk pembiayaan dalam jumlah tertentu

g. Pada hari kerja dan jam kerja yang telah ditetapkan dalam ART.

Setelah bisa menjadi anggota dan daftar untuk mengajukan pembiayaan, anggota bisa menggunakan pembiayaan perdagangan ataupun pertanian, sesuai kebutuhan. Terkait hal ini manager LKMA menjelaskan bahwa dalam pembiayaan akad musyarakah yang ada dalam pertanian dan perdagangan ini, mempunyai perbedaan. Perbedaan ini ada pada waktu dalam pengangsuran. Yakni, dalam pembiayaan pertanian dalam angsurannya bisa mingguan dan juga bulanan. Sedangkan dalam pembiayaan pertanian angsurannya dengan bayar ketika para anggota/petani sudah panen atau sering disebut dengan yarnin, kurang lebih jangka jatuh tempo nya sekitar 4 bulan. Tentunya meringankan anggota jika menggunakan sistem bagi hasil seperti ini.

${ }^{10}$ Ascarya, Akad \& Produk Bank Syariah. Jakarta: PT. Raja Grafindo Persada, 2015,124
${ }^{11}$ SOP dan SOM Lembaga Keuangan Mikro Agribisnis (LKMA) Syariah Amanah Mandiri. 
Seperti yang terungkapkan oleh Ascarya, dengan berbagi hasil kebutuhan modal kerja pihak pengusaha terpenuhi, sementara kedua belah pihak mendapatkan manfaat dari pembagian resiko yang adil. Agar bank syariah dapat berperan aktif dalam usaha dan mengurangi kemungkinan resiko, seperti moral hazard, maka bank dapat memilih untuk menggunakan akad musyarakah. ${ }^{12}$

Menurut peneliti, hal ini cukup meringankan anggota. Namun dalam hal pembiayaan ini nampaknya pihak LKMA sudah mengantisipasi hal-hal yang tidak diinginkan. Jadi pihak LKMA selektif dalam memberi pembiayaan. Hal ini terungkap pada SOP dan SOM yang dimiliki LKMA. Pihak LKMA menghindari pembiayaan seperti: ${ }^{13}$
a. Pembiayaan yang tidak sesuai Syariah
b. Pembiayaan untuk spekulasi
c. Pembiayaan tanpa informasi yang trasparan
d. Pembiayaan pada bidang yang tidak dikuasai
e. Pembiayaan kepada mitra bermasalah

\subsection{Pembahasan}

Penulis mengamati, bahwa akad musyarakah yang ada dalam pembiayaan perdagangan dan pertanian banyak mengalami dampak positif untuk LKMA Syariah Barokah, hal ini seperti yang diuangkapkan oleh manager LKMA bahwa dengan adanya akad musyarakah ini, yang merupakan akad yang paling banyak dugunakan oleh anggota. Dalam sebuah usaha memang ada kenaikan dan penurunan, hal itu juga pernah terjadi di LKMA, dan hal itu merupakan hal yang biasa. Namun, rata-rata perkembangan yang dialami LKMA Syariah Barokah ini nisbah bagi hasilnya mengalami kenaikan secara baik. Hal ini terbukti hingga kini lembaga yang ada di desa Ngepeh kecamatan Loceret ini masih tetap eksis. Syafii juga menambahkan bahwa untuk periode satu terakhir ini mengalami kenaikan dari tahun yang sebelumnya.

Seperti halnya yang diungkapkan Mulya E. Siregar dan Ahmad Buchori, bahwa:

a. Nisbah bagi hasil harus disetujui para pihak di awal akad, kesepakatan nisbah bagi hasil merupakan rukun yang harus dipenuhi dalam akad.

b. Nisbah bagi hasil ditentukan berdasarkan Proyeksi Pendapatan yang akan dihasilkan dan tidak harus berdasarkan porsi modal Musyarakah.

c. Pembayaran bagi hasil ditentukan berdasarkan Nilai Realisasi Pendapatan bukan berdasarkan Nilai Proyeksi Pendapatan

${ }^{12}$ Ascarya, Akad \& Produk Bank Syariah. Jakarta: PT. Raja Grafindo Persada, 2015,125
${ }^{13}$ SOP dan SOM Lembaga Keuangan Mikro Agribisnis (LKMA) Syariah Amanah Mandiri.

Volume 7 No.2 Juli 2020 
Fatwa Dewan Syariah Nasional Majelis Ulama Indonesia (DSN-MUI) memberikan dua metode yang dapat digunakan sebagai standar dalam hal penentuan nisbah bagi hasil dalam akad Musyarakah yakni profit sharing dan revenue sharing.

\section{a. $\quad$ Profit Sharing}

Profit sharing adalah metode perhitungan bagi hasil yang didasarkan pada hasil bersih dari total pendapatan setelah dikurangi dengan biaya yang dikeluarkan untuk memperoleh pendapatan tersebut.

\section{b. Revenue Sharing}

Revenue sharing adalah metode perhitungan bagi hasil didasarkan pada total seluruh pendapatan sebelum dikurangi dengan biaya-biaya yang dikeluarkan untuk memperoleh pendapatan tersebut. ${ }^{14}$

Menurut penulis akad musyarakah dalam pembiayaan perdagangan dan pertanian ini tidak hanya berdampak positif terhadap lembaga saja, namun juga berdampak baik terhadap anggota/nasabah.

Seperti yang diungkapkan oleh Manager LKMA, yakni bapak Puspito, setiap tahunnya dalam lembaga ini lebih sering mengalami peningkatan. Karena anggota merasakan bahwa dalam akad syariah, yang bernama musyarakah ini berbasis ending atau berbasis hasil. Jadi lembaga menarik bagi hasil jika anggota dalam usahanya ada hasilnya, jika gagal panen, maka lembaga tidak akan menarik bagi hasil. Namun, gagal panen yang dimaksud disini adalah di luar kendali lembaga atau takdir. Hal ini dilakukan untuk kemaslahatan bersama-sama.

Hal ini sesuai dengan teori yang dikemukakan oleh Ascarya, bahwa kepuasan dalam islam tidak hanya terbatas pada benda-benda konkrit (materi), tetapi juga tergantung pada sesuatu yang bersifat abstrak, seperti amal shalih yang dilakukan manusia. Oleh karena itu, perilaku dalam ekonomi Islam tidak didominasi oleh nilai alami yang dimiliki oleh setiap individu manusia, tetapi ada nilai luar diri manusia yang kemudian membentuk perilaku ekonomi mereka, yaitu Islam itu sendiri yang diyakini sebagai tuntunan utama dalam hidup dan kehidupan manusia. Jadi, perilaku ekonomi dalam Islam cenderung mendorong keinginan perilaku ekonomi sama dengan kebutuhannya, yang dapat direalisasikan dengan adanya nilai norma dalam akidah dan akhlak. ${ }^{15}$

\section{KESIMPULAN}

${ }^{14}$ Mulya E. Siregar dan Ahmad Buchori, Standar Produk Perbankan Syariah Musyarakah dan Musyarakah Mutanaqishah, Jakarta, Otoritas Jasa Keuangan, 2016, 34-45

${ }^{15}$ Ascarya, Akad \& Produk Bank Syariah. Jakarta: PT. Raja Grafindo Persada, 2015, 6. 
Berdasarkan hasil penelitian yang dilakukan di Lembaga Keuangan Mikro Agribisnis (LKMA) Syariah Barokah ini, dapat disimpulkan beberapa hal mengenai akad musyarakah dalam pembiayaan perdagangan dan pertanian, sebagai berikut:

a. Di LKMA terdapat produk-produk pembiayaan syariah, diantaranya adalah Musyarakah, Mudharabah, Murabahah, Qordul Hasan, Ar Rahn (gadai syariah) dan Ijarah Munahiya Bittamlik. Namun yang kini masih berjalan adalah akad musyarakah dan mudharabah. Dan anggota yang paling mendominasi adalah dalam akad musyarakah. Musyarakah merupakan kerja sama dua pihak antara shahibul mal dengan pengelola dana.

b. Dalam hal pembiaayan musyarakah di LKMA ini, membiayai dua bidang, yakni pembiayaan perdagangan dan pertanian. Pembiayaan perdagangan skimnya mingguan, dan bulanan. Sedangkan pembiayaan pertanian skimnya sekali bayar panen (sekitar 4 bulan).

c. Dengan adanya akad musyarakah ini, lembaga mengalami perkembangan baik, dibuktikan dengan anggotanya paling banyak di akad ini, dan lembaga tetap exis sampai saat ini, tidak hanya itu, pihak anggota pun juga merasa di untungkan, karena dalam akad musyarakah disini menggunakan basis ending atau bagi hasil.

\section{UCAPAN TERIMA KASIH}

Pada kesempatan ini, penulis mengucapkan ucapan terimakasih tak terhingga kepada bebrapa pihak atas terselesaikannya penelitin ini, di antaranya:
a. Rektor IAI Diponegoro Nganjuk
b. Segenap Civiyas akademika IAI Diponegoro Nganjuk
c. Kepada LKMA Syariah Barokah
d. Kepada anggota LKMA Syariah Barokah

\section{REFERENSI}

Ascarya, Akad \& Produk Bank Syariah. Jakarta: PT. Raja Grafindo Persada, 2015.

el-Qurthuby, Usman. Multazam Al-Qur'an Tafsir Bil Hadis, Bandung, Cordoba, 2016.

Ibrahim, Metodologi Penelitian Kualitatif, Bandung: Alfabeta, 2015.

Iswanto, Juni. "Pelaksanaan Jual Beli Hasil Pertanian Dengan Cara Borongan Ditinjau Dari Fiqih Muamalah Di Desa Mancon Kecamatan Wilangan Kabupaten Nganjuk". Jurnal Dinamika Ekonomi Syariah 6, no. 2 (July 1, 2019): 146-165.

Masyhuri, Teori Ekonomi dalam Islam, Yogyakarta, Kreasi Wacana, 2015.

Rahayu, Anik. Akuntansi Akad Musyarakah Mutanaqisah dalam Pembiayaan Kredit Pemilikan Rumah pada PT.Bank Muamalat, Jurnal Ilmu \& Riset Akuntansi Vol. 2 No. 112013. 
Samiudin, Problematika Penulisan Spenelitian, Panca Wahana, Vol. 10, No. 1, 2015.

Maskur, Alfin. "Strategi Penerapan Akad Musyarakah Pada Bidang Pertanian Di Lembaga Keuangan Mikro Agribisnis (LKMA) Amanah Mandiri Sekarputih, Nganjuk". Jurnal Dinamika Ekonomi Syariah 6, no. 1 (January 1, 2019): 1-9.

Siregar, Mulya E. dan Ahmad Buchori, Standar Produk Perbankan Syariah Musyarakah dan Musyarakah Mutanaqishah, Jakarta, Otoritas Jasa Keuangan, 2016.

SOP dan SOM Lembaga Keuangan Mikro Agribisnis (LKMA) Syariah Amanah Mandiri.

Zakariya, Mukhamad. "Peran Lembaga Keuangan Mikro Agribisnis (LKM-A) Amanah Mandiri Syari'ah Terhadap Kelompok Tani Di Desa Sekarputih Kecamatan Bagor Kabupaten Nganjuk". Jurnal Dinamika Ekonomi Syariah 6, no. 2 (July 1, 2019): 183-199. 